\section{B A Institute of \\ YK Business Administration \\ 六下 \\ Karachi \\ Leadership and Ideas for Tomorrow}

Business Review

Volume 10 Issue 1 January - June 2015

$1-1-2015$

\title{
The ex-dividend day stock price behavior: Evidence from Pakistan
}

\author{
Sana Tauseef \\ Institute of Business Administration, Karachi, Pakistan \\ Mohammad Nishat \\ Institute of Business Administration, Karachi, Pakistan
}

Follow this and additional works at: https://ir.iba.edu.pk/businessreview

Part of the Finance Commons

\section{(c) (1)}

This work is licensed under a Creative Commons Attribution 4.0 International License.

\section{Recommended Citation}

Tauseef, S., \& Nishat, M. (2015). The ex-dividend day stock price behavior: Evidence from Pakistan. Business Review, 10(1), 21-30. Retrieved from https://doi.org/10.54784/1990-6587.1311

This article is brought to you by iRepository for open access under the Creative Commons Attribution 4.0 License and is available at https://ir.iba.edu.pk/businessreview/vol10/iss1/3. For more information, please contact irepository@iba.edu.pk. 


\title{
ARTICLE
}

\section{THE EX-DIVIDEND DAY STOCK PRICE BEHAVIOR: EVIDENCE FROM PAKISTAN}

\author{
Sana Tauseef \\ Institute of Business Administration Karachi, Pakistan \\ Mohammad Nishat \\ Institute of Business Administration Karachi, Pakistan
}

\begin{abstract}
The paper examines the ex-dividend day price behavior of the listed stocks in Karachi Stock Exchange for the period January 2009 to June 2010. During the examined period, there was no capital gain tax; however a 10\% withholding tax applied on dividends. We use the standard event study methodology to examine the abnormal returns for days surrounding the exdividend day. The study reports a very low price drop ratios compared to their theoretical values. No significant excess returns are found on the exdividend day; however, significant positive abnormal returns are observed in the pre-event window and negative excess returns are observed in the post event window. The study provides evidence of short-term trading hypothesis surrounding the ex-dividend days on Karachi Stock Exchange.
\end{abstract}

Key Words: Ex-Dividend Date, Clientele Effect, Market Microstructure, Short-Term Trading, Karachi Stock Exchange.

\section{JEL Classification: G35, G14}

\section{Introduction}

In the absence of taxes, transaction costs and uncertainty, the stock price on the exdividend day must drop by the amount of dividend. The proposition given by Miller and Modigliani (1961) implied that the investors are indifferent to either dividend income or capital gains. In one of the early studies, Campbell and Beranek (1955) observed an average stock price drop by an amount slightly less than the dividend on the ex-dividend date, making a tax-paying individual better-off through selling the stock before an ex-dividend date. Since then, studies have been conducted in different markets and reported deviation from the predictions of Miller and Modigliani (1961). Different explanations are given for these deviations. Most popular theories include the tax clientele, short-term trading and market microstructure theories.

Elton and Gruber (1970) suggested that the ex-dividend behavior of a corporation's common stock is related to the tax rate of its marginal stockholders. Their work supported the "clientele effect', suggesting that the investors in high income tax brackets prefer to hold low dividend yield stocks, while those in lower income tax brackets will keep their holdings in high dividend yield stocks. The study reported a positive correlation between the ex-dividend relative price drop and the dividend yield. Milonas, Travlos, Xiao and Tan (2002) examined the ex-dividend day prices in Chinese stock market, where the cash dividends could either be taxable or non-taxable, depending on their magnitude relative to the one-year estimated interest income on the face value of the corresponding stocks. The empirical findings from China are consistent with the tax hypothesis. The prices of the non-taxable stocks on the exdividend day decline by the amount of dividend paid, regardless of the dividend yield. For the 
taxable stocks with low dividend yields, the ex-dividend day prices drop by an amount equal to the tax-adjusted dividend. However, with an effective tax rate of $20 \%$ on dividend income, high dividend yield stocks experience a price drop larger than the tax-adjusted dividend.

According to Kalay (1982), the marginal tax rates of stockholders cannot be inferred from the relative price drop since the tax differential is not the only reason for the ex-day price movement. Kalay argues that the institutional investors who face the same tax rate on dividends and capital gains have non-tax related reasons for entering the market and they arbitrage the price differentials up to the limit posed by the transaction costs. The presence of abnormally high trading volumes around the ex-day is an evidence of short-term trading. Dasilas (2007) investigated the ex-dividend stock price and trading volume behavior in the Greek stock market where there are no taxes imposed on dividends and capital gains. The study concluded that despite of the inexistence of taxes, the ex-day price did not drop by the full amount of dividend, thus supporting the short-term trading hypothesis. The study also reported significant abnormal returns on the ex-dividend day and abnormal trading volume concentrated on the last cum-dividend day and ex-dividend day. Borges (2009) rejected the tax clientele hypothesis and reported the presence of positive abnormal trading volumes surrounding the ex-days. He concluded that the transaction costs restrict the arbitrage opportunities and so there are no market forces pushing the price to a unique market equilibrium.

Market microstructure theories relate the ex-day price behavior to the market frictions arising from price discreteness and bid-and-ask spreads. Bali and Hite (1998) proposed this model and claimed that the ex-day price of a stock will change by a price increment equal to or just smaller than the size of the dividend payment. If the dividend is not a multiple of minimum tick size, then the price drops by less than the dividend. Borges (2009) ruled out the price discreteness model by observing price drop lesser than dividend for Portuguese market where the price tick is very small and dividends are always integer multiples of tick size.

In the recent past, a few researches have been conducted to study the determinants of dividends and the reaction to dividend announcement at Karachi Stock Exchange. Ahmed and Javid (2009) examined the determinants of dividend payout policy of non-financial firms listed in Karachi Stock Exchange using a sample of 320 firms. The results showed that dividend payments in Pakistan are more sensitive to current earnings than the prior dividend payments. The ownership structure was also found to have a major impact on the dividend payout decision. The firms with major inside shareholdings pay more dividends to their shareholders in Pakistan. Moreover, the market capitalization and firm size were found to have a negative impact on the dividend payout of Pakistani firms. Akbar and Baig (2010) in their study to test the semi-strong form of market efficiency in Pakistan found that the reaction of stock prices to cash dividend announcements is statistically insignificant. The returns (ignoring) during the 41-day event window were found to be mostly negative, which might be attributed to the tax effect of cash dividends. The results for stock dividend announcements and for simultaneous cash and stock dividends were found to be positive and significant. The positive reaction to stock dividends was attributed to the zero taxes on stock dividends and capital gains in Pakistan's equity market. No research, so far, is done to explore the ex-dividend day price movement for Pakistani stocks. This study extends the international evidence on the ex-dividend day stock price behavior by studying Pakistani stocks and tests the different theoretical explanations proposed for the ex-day price reaction for Pakistani market. 


\section{Karachi Stock Exchange}

Karachi Stock Exchange (KSE) is the biggest and most liquid exchange in Pakistan. As of December, 2009, 654 companies were listed on KSE with a market capitalization of Rs. 2.561 trillion (US\$ 30.5 billion).

There are three general forms of dividends that the companies listed on KSE declare and pay: Cash, Stock (bonus shares), and a combination of two. There is a $10 \%$ withholding tax applied on the cash dividends on KSE. On the capital gains, no tax was applicable for the examined period. However, in Feb 2010, the government and directors of Karachi Stock Exchange (KSE) decided to have a capital gain tax effective from July 1, 2010.

\section{Data and Methodology}

The sample includes all listed stocks that paid cash dividends during the period from January 2009 to June 2010. The stocks offering the bonus dividends or stock splits with the cash dividend payments are excluded from the sample. The sample initially consisted of 269 dividend payments. From these dividend distributions, we have included the stocks having at least 200 trading days prior to the dividend payment date. On basis of the availability of stock prices over the event and estimated window, our final data, consists of 236 cash dividend distributions. Data on all dividend payment events by the listed firms during the covered period was collected from the website of Karachi Stock Exchange (www.kse.com.pk). The daily share prices and trading volumes for the sample stocks and market indices for KSE were obtained from the website of Daily Business Recorder (www.brecorder.com.pk).

We use a number of approaches to analyze the stock price drop around the exdividend date. Considering no taxes on dividends and capital gains and no transaction costs, the price drop on the ex-dividend day is equal to the amount of dividend paid. Let $\mathrm{P}_{\mathrm{c}}$ the closing price on the cum-dividend day, $\mathrm{P}_{\mathrm{e}}$ the closing price on ex-dividend day and $\mathrm{D}$ the amount of dividend paid, then

$$
\mathrm{P}_{\mathrm{c}}-\mathrm{P}_{\mathrm{e}}=\mathrm{D}
$$

If we divide both sides by $\mathrm{D}$, we get the raw price ratio (RPR):

$$
R P R=\left(P_{c}-P_{e}\right) / D=D / D=1
$$

The raw price ratio measures the price change from the last cum-dividend day to the exdividend day in terms of dividend paid and has a theoretical value of 1 .

In the case where dividends are taxable, we can rewrite equations (1) and (2) by taking into account the tax that must be paid on the dividends. With a $10 \%$ tax on dividends, the equations can be re-written as follows:

$$
\begin{aligned}
& \mathrm{P}_{\mathrm{c}}-\mathrm{P}_{\mathrm{e}}=0.90 * \mathrm{D} \\
& \mathrm{RPR}=\left(\mathrm{P}_{\mathrm{c}}-\mathrm{P}_{\mathrm{e}}\right) / \mathrm{D}=(0.90 * \mathrm{D}) / \mathrm{D}=0.90
\end{aligned}
$$

Because the raw price ratio is subject to market influences between the two days, we adjust the ex-day closing price for the market return by discounting the ex-dividend price by the market return, proxied by KSE 100 index, between the two days. Ignoring taxes, this marketadjusted price ratio (MAPR) has a theoretical value of 1 and is given as:

$$
\operatorname{MAPR}=\left[\mathrm{P}_{\mathrm{c}}-\left(\mathrm{P}_{\mathrm{e}}\right) /\left(1+\mathrm{R}_{\mathrm{m}}\right)\right] / \mathrm{D}
$$

The price change given by equation (2) can also be expressed in terms of the price on last cum-dividend day. The ratio called the raw price drop ratio is given as: 


$$
\operatorname{RPDR}=\left(\mathrm{P}_{\mathrm{c}}-\mathrm{P}_{\mathrm{e}}\right) / \mathrm{P}_{\mathrm{c}}
$$

As before we can also adjust the raw price drop ratio for market influences between the last cum-dividend day and the ex-dividend day to get the market-adjusted price drop ratio:

$$
\operatorname{MAPDR}=\left[\mathrm{P}_{\mathrm{c}}-\left(\mathrm{P}_{\mathrm{e}}\right) /\left(1+\mathrm{R}_{\mathrm{m}}\right)\right] / \mathrm{P}_{\mathrm{c}}
$$

Ignoring taxes on dividends, all raw price drop ratios have a theoretical value equal to the dividend yield (DY) which is computed as the dividend per share divided by the stock price on the last cum-dividend day.

$$
\mathrm{DY}=\mathrm{D} / \mathrm{P}_{\mathrm{c}}
$$

With a $10 \%$ tax on dividends, the value for price drop ratios should equal $0.90 * \mathrm{DY}$.

Finally, the abnormal raw returns on the ex-dividend days is calculated as given:

$$
\operatorname{ARR}=\left(\mathrm{P}_{\mathrm{e}}+0.90 * \mathrm{D}-\mathrm{P}_{\mathrm{c}}\right) / \mathrm{P}_{\mathrm{c}}
$$

Our study tests the following null hypotheses:

$$
\begin{aligned}
& \mathbf{H}_{1}=\text { The mean of } \mathrm{RPR}=0.90 \\
& \mathbf{H}_{\mathbf{2}}=\text { The mean of MAPR }=0.90 \\
& \mathbf{H}_{\mathbf{3}}=\text { The mean of } \mathrm{RPDR}=0.90 * \mathrm{DY} \\
& \mathbf{H}_{\mathbf{4}}=\text { The mean of MAPDR }=0.90 * \mathrm{DY} \\
& \mathbf{H}_{\mathbf{5}}=\text { The mean of ARR }=0
\end{aligned}
$$

We also examine the market reaction on and around the ex-dividend days using the standard event study methodology. The event window has been taken from $t=-20$ to $t=+20$, where $t=-$ 20 represents 20 days before the ex-dividend date $(t=0)$ and $t=+20$ represents 20 days after the stock goes ex-dividend. We employ the single-factor market model to compute the abnormal return for each stock in the 40-day window. The market model parameters are computed using an estimation period of 180 days before the window period for each participating firm. The period of 20 days prior to the ex-dividend date is not included in this clean period to prevent the event's influence on the parameter estimates.

The following market model is employed for the parameter estimations:

$$
\mathbf{A} \mathbf{R}_{i t}=\mathbf{R}_{i t}-\mathbf{E}\left(\mathbf{R}_{i t}\right)
$$

where,

$$
\begin{aligned}
& \mathrm{AR}_{i t}=\text { Abnormal return for stock } i \text { on day } t . \\
& \mathrm{R}_{i t}=\text { Actual return of stock } i \text { at time } t .
\end{aligned}
$$

$\mathrm{E}\left(\mathrm{R}_{i t}\right)=$ Expected return on stock $i$ at time $t$. This is measured by the following equation: $\mathbf{E}\left(\mathbf{R}_{i t}\right)=\boldsymbol{\alpha}+\boldsymbol{\beta} \mathbf{R}_{m t}$

$\alpha=$ Ordinary least squares estimate of the intercept of the market model regression.

$\beta=$ Ordinary least squares estimate of the coefficient in the market model regression. 
The cumulative abnormal returns are computed for the period surrounding the ex-dividend days $(-20$ to +20$)$, i.e., from 20 days before the ex-dividend date to 20 days after the exdividend date, using the following equation:

$$
t=20
$$

$$
\mathbf{C A R}=\sum \mathbf{A R}_{t}
$$

We anticipate a mean abnormal return on ex-days and a cumulative abnormal return pre- and post-ex-dividend period equal to zero. That is, the null hypotheses are:

$$
\begin{aligned}
& \mathbf{H}_{6}=\text { The mean of abnormal returns on ex-days (ARs) }=0 \\
& \mathbf{H}_{7}=\text { The cumulative abnormal returns pre- and post-ex-dividend period }(\mathrm{CARs})=0
\end{aligned}
$$

\section{Empirical Results}

Exhibit 1 shows the descriptive statistics of the sample dividend payments. The mean dividend is PKR4.718 and the mean dividend yield is 5.5\%. The average price change on ex-dividend day is -0.202 indicating that on average, the stock prices have slightly increased on the ex-dividend days for the observed period. The mean raw price ratio (RPR) is 0.010 and the market adjusted price ratio (MAPR) is 0.033 . The mean abnormal raw return on ex-dividend day is $4.9 \%$.

The mean RPR, mean MAPR, mean RPDR, mean MAPDR, mean ARR and the theoretical values of these ratios are given in exhibit 2. T-statistics to measure the differences of the means from their corresponding theoretical values are also presented in the exhibit. The mean RPR, mean MAPR, mean RPDR, and mean MAPDR ratios are all very small compared to their theoretical values.

Exhibit 1: Descriptive Statistics

\begin{tabular}{|l|l|l|l|l|l|l|l|l|}
\hline$n=236$ & Dividend & Div. Yield & $P_{c}-P_{e}$ & RPR & MAPR & RPDR & MAPDR & ARR \\
\hline Mean & 4.718 & 0.055 & -0.202 & 0.010 & 0.033 & 0.001 & 0.001 & 0.049 \\
\hline Standard Deviation & 7.477 & 0.053 & 9.846 & 1.914 & 2.001 & 0.035 & 0.037 & 0.058 \\
\hline Minimum & 0.010 & 0.003 & -58.360 & -11.672 & -17.459 & -0.081 & -0.119 & -0.266 \\
\hline Maximum & 60.000 & 0.338 & 67.000 & 15.073 & 16.046 & 0.283 & 0.301 & 0.301 \\
\hline Range & 59.990 & 0.335 & 125.360 & 26.745 & 33.505 & 0.364 & 0.420 & 0.567 \\
\hline
\end{tabular}

The mean RPR (0.010) with a t- statistic of -7.145 and mean MAPR (0.033) with a tstatistic of -6.659 are statistically lesser compared to their theoretical values. The mean RPDR is 0.001 with a t-statistic of -21.378 and mean MAPDR is 0.001 with a t-statistic of -19.983 . These two ratios are also statistically lower than their theoretical values. The abnormal raw return (ARR) of $4.9 \%$ has a t-statistic of 12.96 and is significantly positive. These results, thus, reject the hypothesis that the stock prices drop by the after-tax dividend amount on ex- 
dividend days on Karachi Stock Exchange. On KSE, the ex-dividend day price decline is not equal to the tax-adjusted amount of dividend. The price drop is significantly lesser than the tax-adjusted dividend and therefore, the tax hypothesis does not explain the ex-day price behavior of Pakistani stocks. The results are consistent with the results of the similar study conducted in Greece which also reported the inexistence of the stock price drop equal to the dividend amount on ex-days (Dasilas, 2007).

Exhibit 3 and 4 give the average abnormal returns and cumulative abnormal returns for the dividend paying stocks for a 41-day event window surrounding the ex-dividend days. The excess returns and CARs are calculated using the single factor market model. On the exdividend day $(\mathrm{t}=0)$, the mean $\mathrm{AR}$ is $-0.163 \%$ and is not statistically significant. However, positive and significant excess returns are observed on some days in the event period. These positive ARs are clustered in the pre-event period. There is an AR of $0.308 \%$ on day -3 and is significant at $5 \%$. On day $-5, \mathrm{AR}$ is $0.31 \%$ and is significant at $10 \%$.

Exhibit 2: Ex-Dividend Day Price Behavior

\begin{tabular}{|l|l|l|l|}
\hline$n=236$ & Theoretical Value & Mean & t-Statistic \\
\hline RPR & 0.900 & 0.010 & -7.145 \\
\hline MAPR & 0.900 & 0.033 & -6.659 \\
\hline RPDR & 0.050 & 0.001 & -21.378 \\
\hline MAPDR & 0.050 & 0.001 & -19.982 \\
\hline ARR & 0.000 & 0.049 & 12.960 \\
\hline
\end{tabular}

* Significant at $1 \%$

Exhibit 4 displays the average cumulative abnormal returns over the event period. Mean CAR shows an increasing trend since 20 days prior to the ex-day till the last cum-day. On this day $(\mathrm{t}=-1)$, the mean CAR is $4.10 \%$. Since the ex-dividend day, the average CAR decreases till 7 days after the ex-day when it reaches $2.963 \%$.

Exhibit 3: ARs and CARs surrounding the Ex-Dividend Days

\begin{tabular}{|l|l|l|l|l|l|l|}
\hline Event Day & Avg. AR & Std. Dev & t-statistic & Avg. CAR & Std Dev & t-statistic \\
\hline-20 & 0.002815323 & 0.035906222 & 1.204521219 & 0.002791464 & 0.035754038 & 1.19939689 \\
\hline-19 & 0.004490403 & 0.049000021 & 1.407813289 & 0.00726284 & 0.063795241 & 1.748937089 \\
\hline-18 & 0.002078567 & 0.043378544 & 0.736113969 & 0.009341407 & 0.078938688 & 1.817935144 \\
\hline-17 & -0.001128693 & 0.033759705 & -0.513609479 & 0.008212714 & 0.088221754 & 1.430102038 \\
\hline-16 & 0.00215905 & 0.028246027 & 1.174251849 & 0.010371764 & 0.09640049 & 1.652834541 \\
\hline-15 & 0.00178837 & 0.030496956 & 0.90085921 & 0.012160134 & 0.106030195 & 1.761833256 \\
\hline
\end{tabular}


Business Review - Volume 10 Number 1

January - June 2015

\begin{tabular}{|c|c|c|c|c|c|c|}
\hline-14 & 0.002291793 & 0.029838925 & 1.179908243 & 0.014451927 & 0.112141454 & 1.979773843 \\
\hline-13 & 0.001319796 & 0.03118935 & 0.650064791 & 0.015771724 & 0.118049726 & 2.052438606 \\
\hline-12 & 0.001272329 & 0.028648587 & 0.68226337 & 0.017044052 & 0.121289683 & 2.158763138 \\
\hline-11 & 0.003485152 & 0.035360206 & 1.514129325 & 0.020529204 & 0.129327797 & 2.438575684 \\
\hline-10 & 0.007407368 & 0.035828161 & 3.176108921 & 0.027936572 & 0.138810303 & 3.091771661 \\
\hline-9 & 0.001352804 & 0.032849978 & 0.632638835 & 0.029289376 & 0.144240608 & 3.119453937 \\
\hline-8 & 0.002730928 & 0.031165 & 1.346167789 & 0.032020305 & 0.147174579 & 3.342324856 \\
\hline-7 & 0.001752954 & 0.025370168 & 1.061459142 & 0.033773259 & 0.155393429 & 3.338845494 \\
\hline-6 & 0.000323957 & 0.026463959 & 0.188056841 & 0.034097216 & 0.157767614 & 3.320145144 \\
\hline-5 & 0.003139218 & 0.026450289 & 1.823253673 & 0.037236435 & 0.161776219 & 3.535976831 \\
\hline-4 & 0.00158229 & 0.024669747 & 0.985320102 & 0.038818724 & 0.165623013 & 3.600614128 \\
\hline-3 & 0.003083475 & 0.023029587 & 2.056886154 & 0.041902199 & 0.171681992 & 3.749454388 \\
\hline-2 & -0.002294258 & 0.027605892 & -1.276722318 & 0.039607941 & 0.172578715 & 3.525746168 \\
\hline-1 & 0.001403483 & 0.039106927 & 0.551327349 & 0.041011425 & 0.172483542 & 3.652693197 \\
\hline $\mathbf{0}$ & -0.001628118 & 0.032386159 & -0.77229355 & 0.039383307 & 0.177276035 & 3.412857454 \\
\hline 1 & -0.002481455 & 0.026134629 & -1.45863308 & 0.036901852 & 0.181588546 & 3.121876436 \\
\hline 2 & -0.002762924 & 0.02998637 & -1.415471453 & 0.034138927 & 0.184669233 & 2.839954131 \\
\hline 3 & -0.000202003 & 0.028142556 & -0.110268117 & 0.033936924 & 0.186126587 & 2.801044886 \\
\hline 4 & -0.001992726 & 0.035455676 & -0.863411419 & 0.031944199 & 0.194974205 & 2.516928278 \\
\hline 5 & -0.002131812 & 0.02938273 & -1.114584073 & 0.029812386 & 0.196580989 & 2.329760217 \\
\hline 6 & 3.06798E-05 & 0.029861587 & 0.015783229 & 0.029843066 & 0.197386794 & 2.322637051 \\
\hline 7 & -0.000208136 & 0.030073571 & -0.106320861 & 0.02963493 & 0.198689881 & 2.29131162 \\
\hline
\end{tabular}




\begin{tabular}{|l|l|l|l|l|l|l|}
\hline 8 & 0.000910408 & 0.027330183 & 0.511740215 & 0.030545338 & 0.202383279 & 2.318602543 \\
\hline 9 & 0.000215425 & 0.032514607 & 0.101782688 & 0.030760763 & 0.207987666 & 2.272037657 \\
\hline 10 & 0.000482333 & 0.029933347 & 0.247541479 & 0.031243096 & 0.210698504 & 2.277973248 \\
\hline 11 & 0.000549957 & 0.030559266 & 0.276466284 & 0.031793054 & 0.217486576 & 2.245720959 \\
\hline 12 & 0.00358907 & 0.028672721 & 1.922954319 & 0.035382124 & 0.225360738 & 2.411913005 \\
\hline 13 & -0.002344773 & 0.024904756 & -1.446353403 & 0.033037351 & 0.228609622 & 2.220070235 \\
\hline 14 & 0.000589479 & 0.026976974 & 0.335684486 & 0.03362683 & 0.230141729 & 2.244639291 \\
\hline 15 & 0.00089711 & 0.027625016 & 0.498883716 & 0.034523941 & 0.230911595 & 2.296839354 \\
\hline 16 & 0.002118491 & 0.04701951 & 0.692156818 & 0.036642431 & 0.231534502 & 2.431221736 \\
\hline 17 & 0.002899193 & 0.034307517 & 1.298206591 & 0.039541624 & 0.232605874 & 2.611498787 \\
\hline 18 & 0.001982424 & 0.029002949 & 1.05005096 & 0.041524048 & 0.234798516 & 2.716816714 \\
\hline 19 & 0.000706711 & 0.0316208 & 0.343340432 & 0.042230759 & 0.241155398 & 2.690220648 \\
\hline 10 & -0.001423589 & 0.032536676 & -0.672151945 & 0.04080717 & 0.241710666 & 2.593562179 \\
\hline 10 & & & & & & \\
\hline 10 & & & & &
\end{tabular}

Exhibit 4: ARs and CARs surrounding the Ex-Dividend Days

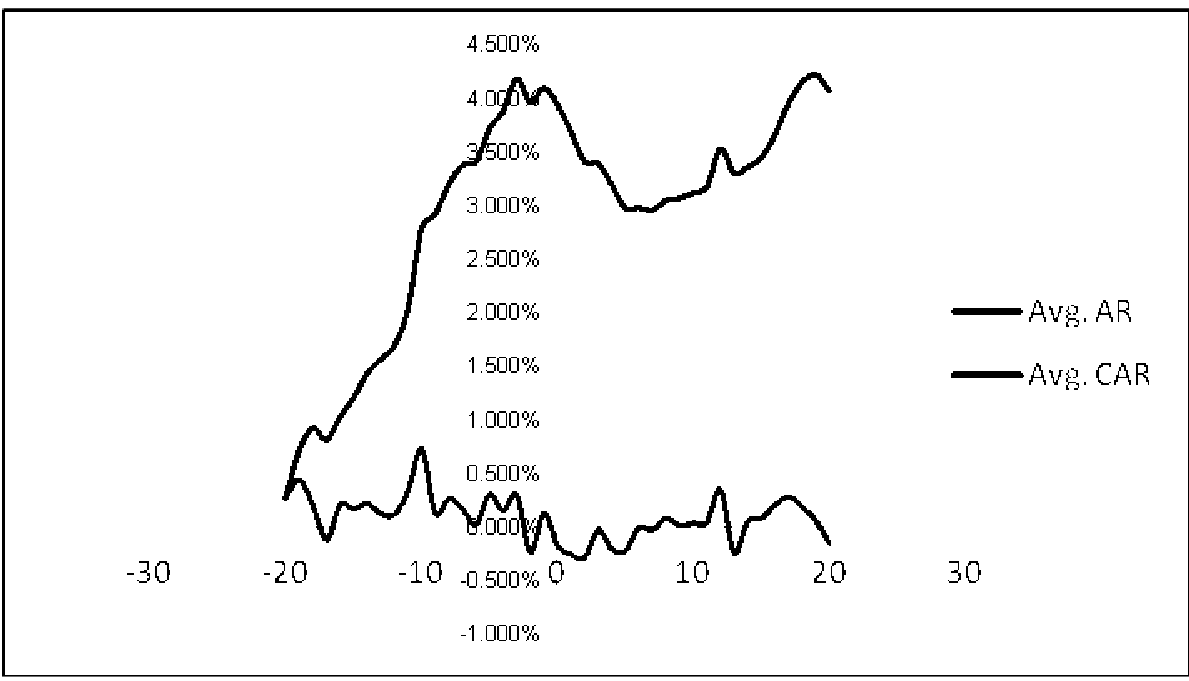


Exhibit 5 shows the mean CAR over the various sub-periods in the total event window of 41 days. CARs for all sub periods prior to ex-day are positive. The highest CAR is accumulated for the period -20 to -10 , which is the period closest to the dividend announcement date. For the period after ex-day, CAR declines. The decrease in CAR is mostly concentrated in the first 5 days after the ex-day. The CAR values over the various event periods are consistent with the short-term trading hypothesis, which suggests positive price changes in the pre-event period due to buying pressures and negative price changes in the post period due to selling pressures.

Exhibit 5: Mean CAR for Sub-Periods

\begin{tabular}{|c|c|c|c|c|c|c|c|}
\hline $\begin{array}{l}\text { Sub- } \\
\text { period }\end{array}$ & $\begin{array}{l}-20 \\
\text { to } \\
-10\end{array}$ & $\begin{array}{l}-10 \\
\text { to } \\
-5\end{array}$ & $\begin{array}{l}-5 \\
\text { to } \\
-1\end{array}$ & 0 & $\begin{array}{l}+1 \\
\text { to } \\
+5\end{array}$ & $\begin{array}{l}+6 \\
\text { to } \\
+10\end{array}$ & $\begin{array}{l}+11 \\
\text { to } \\
+20\end{array}$ \\
\hline CAR & 2.5145 & 0.9299 & 0.3775 & -0.1628 & -0.9571 & 0.1431 & 0.9564 \\
\hline
\end{tabular}

Conclusion:

The study examines the ex-dividend day price behavior on Karachi Stock Market during the period January 2009 to June 2010. For the examined period there was no capital gains tax while a tax of $10 \%$ applied on the dividends. The price drop ratios are reported to be smaller compared to their theoretical values, indicating a lesser drop in price compared to the tax-adjusted dividends. The study also examines the abnormal returns surrounding the exdays using the single-factor market model. The study evidences the existence of short-term trading and reports positive abnormal returns concentrated in the pre-event window and negative abnormal returns in the post-event period.

The study provides the evidence from the period where tax is applicable only on dividends and no tax is applied on capital gains. Since the capital gain tax has been implemented in Karachi Stock Exchange effective from July 1, 2010, future research can examine the ex-day price behavior when the tax is applicable on both dividends and capital gains. 笰

\section{References}

Ahmed, H. and Javid, A. (2009). Dynamics and Determinants of Dividend Policy in Pakistan (Evidence from Karachi Stock Exchange Non-Financial Listed Firms). International Research Journal of Finance and Economics, Vol. 25, pp. 148-171.

Akbar, M. and Baig, H. H. (2010). Reaction of Stock Prices to Dividend Announcements and Market Efficiency in Pakistan. The Lahore Journal of Economics,Vol. 15, No. 1, pp. 103-125.

Bali, R. and Hite, G. L. (1998). Ex-Dividend Day Stock Price Behavior: Discreteness or TaxInduced Clienteles. Journal of Financial Economics, Vol. 47, No. 2, pp. 127-159.

Borges, M. R. (2009). A Model of Stock Price Adjustment after Dividends. Journal of Economic Studies, Vol. 36, No. 5, pp. 508-521. 
Campbell, J. A. and Beranek, W. (1955). Stock Price Behavior on Ex-Dividend Dates. The Journal of Finance, Vol. X, No. 4, pp. 425-429.

Dasilas, A. (2007). The Ex-Dividend Day Stock Price Anomaly: Evidence from Greece.

Durand, D. and May, A. M. The Ex-Dividend Behavior of American Telephone and Telegraph Stock. The Journal of Finance, pp. 19-31.

Elton, E. and Gruber, M. (1970). Marginal Stockholders Tax Rates and the Clientele Effect. Review of Economics and Statistics, Vol. 52, pp. 68-74.

Kalay, A. (1982). The Ex-Dividend Day Behavior of Stock Prices: A Re-examination of Clientele Effect. Journal of Finance, Vol. 38, pp. 1059-1070.

Miller, H. M. and Modigliani, F. (1961). Dividend Policy, Growth, and the Valuation of Shares. Journal of Business, Vol. 34, pp. 411-433.

Milonas, N., Travlos, N., Xiao, J.Z. and Tan, C. (2002). The Ex-Dividend Day Stock Price Behavior in the Chinese Stock Market.

Shah, S. Z. A.,Yuan, H. and Zafar, N. (2010). Earnings Management and Dividend Policy: An Empirical comparison between Pakistani Listed Companies and Chinese listed Companies. International Research Journal of Finance and Economics, Vol. 35, pp. 51-60.

One of the hardest tasks of leadership is understanding that you are not what you are, but what you're perceived to be by others.

Edward I. Flom 